\title{
Undue Influence and the Religious Cases and Shaped the Law
}

\author{
Richard Hedlund*
}

\section{Introduction}

This article will look at three early cases that were influential in developing the modern doctrine of undue influence. Each of the three cases concerned tainted gifts that had been given to religious institutions, and the complaint was that those religious institutions had obtained the gifts after exercising untoward spiritual influence. The aim of the article is to closely investigate each of the three cases, before considering the challenges that religious institutions today face when asking for and accepting large donations. The three cases discussed will help determine where the courts should draw the line as to when to intervene with gift-giving to religious institutions, and what factors the courts can look at today when considering gifts made to religious institutions.

The article will begin by looking at the legal background to the three cases and the tensions already present with regards to gift-giving to religious institutions. The third, fourth and fifth sections will respectively look at three cases, namely Norton $v$ Relly, Nottidge $v$ Prince and Allcard $v$ Skinner. ${ }^{1}$ They span over 120 years, from the 1760s to the 1880s. The sixth section will consider how these cases can help understand the legal position today, and the challenges that religious institutions can face when asking for donations. The historian John Tosh has suggested that looking at "history" can provide 'a less blinkered approach to current problems'. ${ }^{2}$ To put the principles to the test, the sixth section will also look at two more recent cases from Australia, McCulloch v Fern and Hartigan v International Society for Krishna Consciousness. ${ }^{3}$ The article will show that religious institutions are particularly vulnerable to being found liable for undue influence because of the psychological impact that religious devotion can have on people. As such, special care must be taken when religious institutions ask for or accept gifts and donations.

\section{Gifts and Religious Institutions}

\section{A. Undue Influence - an overview}

English law treats valid contracts and gifts which are feely given as irrevocable. The common law recognises a limited number of circumstances where a transaction can be set aside, including duress, fraud, misrepresentation or mistake of facts. ${ }^{4}$ Equity recognised that there are situations in which it should be possible to vitiate contracts or gifts in order to protect people from exploitation. To supplement the law, equity developed the broader concept of equitable fraud. ${ }^{5}$ Equitable fraud included the dual concepts of undue influence and

\footnotetext{
* Richard Hedlund, Lincoln Law School, University of Lincoln. With the usual caveats, I would like to thank Professor Richard Nolan for his helpful comments on the research which preceded this article. I would also like to thank the anonymous reviewers for their helpful comments on an earlier draft.

${ }^{1}$ Norton v Relly (1764) 2 Eden 286, 28 ER 908; Nottidge v Prince (1860) 2 Giff 246, 66 ER 103; Allcard v Skinner (1887) 36 Ch D 145

2 John Tosh, The Pursuit of History, (5 $5^{\text {th }}$ edn, Pearson Education, 2010), 37

${ }^{3}$ McCulloch v Fern [2001] NSWSC 406; Hartigan v International Society for Krishna Consciousness Inc [2002] NSWSC 810

${ }^{4}$ Consider IBM United Kingdom Holdings Ltd v Dalgleish [2015] EWHC 389, [86] (Warren J); Radmacher v Granatino [2010] UKSC 42, [2011] 1 AC 534, [71] (Lord Phillips); Royal Bank of Scotland plc v Etridge (No 2) [2002] 2 AC 773, [6] (Lord Nicholls)

${ }^{5}$ Earl of Chesterfield v Janssen (1751) 2 Ves Sen 125, 155-156; 28 ER 82, 100 (Lord Hardwicke LC)
} 
unconscionable bargains. The Privy Council in Lawrence $v$ Poorah explained that both of those doctrines 'share a common root-equity's concern to protect the vulnerable from economic harm'. ${ }^{6}$ The doctrine of undue influence, which is divided into actual and presumed, allows gifts and contracts to be set aside if one party (the claimant) has entered into the transaction because of some untoward pressure (which can fall short of actual duress) exercised either by the other party to the transaction or, in some instances, by a third party. ${ }^{7}$ The difference is primarily one of who has the ultimate burden of proof; there is no distinction drawn between the kinds of influence actually exercised. ${ }^{8}$ The untoward influence can be overt (such as making actual threats) as well as more covert, subtle, emotional pressure (such as manipulating emotions of familial, parental or romantic love). It is beyond the scope this article to explore the legal principles in any detail. In each case the courts must ask whether the defendant can, in good conscience, retain the benefit of the transaction. ${ }^{9}$ Where the answer is no, relief can be given, usually in the form of setting the transaction aside and restoring the parties to their original position.

The common law has long objected to this broader equitable intervention into contracts and gifts. Bramwell B made this argument in Preston v Dania.

'Where is the injustice of holding people to mean what they say? Where is the injustice of making a man perform what he chooses to promise? I protest I can see none. And to relieve a man from his obligations on some supposed equitable considerations, seems to me to be a mischievous thing', ${ }^{10}$

The point is clearly made. Equity would object, however, on the basis of the conscience of the defendant. It is not about holding claimants to what they might have meant. It is about questioning whether the defendant is entitled to keep the benefit of the contract or the gift, which they should not be entitled to if they have exercised influence or pressure on the claimant. The importance and validity of equitable intervention will become clear once the three cases have been considered.

The religious cases that will be discussed fall under presumed undue influence. The claimant has to prove two things: firstly that they have a relevant relationship with the defendant and secondly that the transaction in question was out of the ordinary. There is an open-ended list of relevant relationships, and can be one of trust and confidence, or one where the defendant gained some psychological, emotional, or financial ascendancy and superiority over the claimant. The relationship between a priest and a congregant is included, at least in circumstances where the clergyman acts as a spiritual advisor. The gift must also be questionable, that is to say, not one which would be normal within the relationship. It then falls to the defendant to rebut the presumption that the transaction is tainted. ${ }^{11}$ This is typically done by showing that the claimant received independent advice. It is very important to note that the claimant does not have to show actual wrongdoing, such as being "forced" or "tricked". ${ }^{12}$ It is not necessary to show that the clergyman with sinister intent pressured the

\footnotetext{
${ }^{6}$ Lawrence v Poorah [2008] UKPC 21, [20] (Lord Walker)

${ }^{7}$ Allcard v Skinner (1887) 36 Ch D 145, 171 (Cotton LJ)

${ }^{8}$ Hart $v$ Burbidge [2013] EWHC 1628, [37] (Sir William Blackburne)

9 Allcard v Skinner (1887) 36 Ch D 145, 190 (Bowen LJ); Hartigan v International Society for Krishna Consciousness Inc [2002] NSWSC 810, [29] (Bryson J)

${ }^{10}$ Preston v Dania (1872-73) LR 8 Ex 19, 22 (Bramwell B); Catherine MacMillan, 'Earl of Aylesford v Morris (1873)' in Charles Mitchell and Paul Mitchell (eds), Landmark Cases in Equity (Hart Publishing, 2012), 342

${ }^{11}$ Re Smith (deceased) [2014] EWHC 3926, [72] (Stephen Morris QC); Allcard v Skinner (1887) 36 Ch D 145, 181 (Lindley LJ)

${ }^{12}$ Niersmans v Pesticco [2004] EWCA Civ 372, [20] (Mummery LJ)
} 
congregant to give money. It is sufficient to show that, even innocently, the defendant had created an atmosphere in which the claimant felt he had little choice but to make the gift.

\section{B. Historical problems with religious gift-giving}

In the first case to be considered, Norton $v$ Relly, the Lord Chancellor noted that this was 'the first of the kind' that had ever come before an English court. ${ }^{13}$ It is not clear, however, whether the Lord Chancellor is saying this is the first undue influence case to be heard in the context of a religious gift, or whether this is the first case where the court had to consider how to approach an alleged Methodist preacher. The former assertion is supported by the fact that Lord Northington does not cite any authority in his judgment. If this was the first undue influence case to arise to set aside a religious gift, it nonetheless arose with the backdrop of centuries of concern about the practice of clerics in inducing congregants to gift property to the Church, such as through wills.

Setting aside a transaction on the basis of an imbalance between the parties was recognised in the medieval canon law. ${ }^{14}$ Helmholz notes that all 'causes involving oppression of the poor called forth the special solicitude of the church'. ${ }^{15}$ One example given is that of a father conveying his son's property at undervalue. The transaction was set aside because of the father's dominance. The language used in undue influence, to protect the weak and the vulnerable, suggests that the doctrine had a canon law origin.

In the Middle Ages there was a concern about clergy pressuring congregants to generously give their property, or parts of it, to the Church. Granting land to the Church was a popular way around paying tax to the feudal lords, until that practice was banned by the 1279 Statute of Mortmain. ${ }^{16}$ This precipitated the "use", the precursor to the trust, as a means of passing land in a tax-efficient manner. Sherman suggests the strict rules of mortmain were based on both the concerns that feudal lords had about loss of income from their lands if it was given in perpetuity to the Church, as well as fears that the Church was exploiting people on their deathbed. ${ }^{17}$ Another mortmain statute was enacted in 1736, during a 'time of rampant anticlericalism in England', when concerns again grew about priests exploiting congregants on their deathbed. ${ }^{18}$ Of course, these concerns are centred on deathbed persuasions, when people are perhaps especially vulnerable and worried about what comes next.

The law has thus for a long time been concerned about donations to religious institutions. The mortmain legislation was perhaps more politically motivated, because of lost tax revenue, than simply concerned about clerical abuses of congregants. Sherman argues that the statutes, some of which remain in use in common law jurisdictions around the world, can be harsh and inflexible, and consequently 'undue influence must continue to serve as the primary bulwark against the imposition by charitable or religious organizations upon the mind and free agency of anxious testators'. ${ }^{19}$ The same applies to inter vivos gifts.

\footnotetext{
${ }^{13}$ Norton $v$ Relly (1764) 2 Eden 286, 287; 28 ER 908, 908 (Lord Northington)

${ }^{14}$ RH Helmholz, The Spirit of Classical Canon Law (The University of Georgia Press, 2010), 96

${ }^{15}$ Ibid, 120

16 AH Oosterhoff, 'The Law of Mortmain: An Historical and Comparative Review' (1977) 27 University of Toronto Law Journal 257, 258; Sandra Raban, Mortmain Legislation and the English Church 1279-1500 (CUP, 1982), 12

${ }^{17}$ Jeffrey G Sherman, 'Can Religious Influence Ever be “Undue” Influence?' (2008) 73 Brooklyn Law Review 579, 581; Oosterhoff (n 16), 267

${ }^{18}$ Sherman (n 17), 596; Oosterhoff (n 16), 282

${ }^{19}$ Sherman (n 17), 616
} 


\section{Norton v Relly}

The early $18^{\text {th }}$ century was a time of religious upheaval in England. The Glorious Revolution of 1688 had not been the last word on the Church of England's status in the country. There were many nonconformist or dissenting groups, including Calvinists, Baptists, and later Methodists, as well as Catholics. ${ }^{20}$ The middle part of the $18^{\text {th }}$ century also saw the start of the industrial revolution, and the latter half saw the political revolutions in the United States and France; each prompted consideration of religious dissent. ${ }^{21}$

The social changes that came with the industrial revolution are well known. There was rapid urbanisation, as people from the countryside moved to the cities to find work in the factories. Industrial cities, primarily in the north of England, such as Manchester, Huddersfield and Leeds grew rapidly. In these conditions there was widespread poverty. An old Elizabethan law was used to strictly regulate the working environment meaning in effect that a worker could not unilaterally leave his job and trade unions were technically illegal. ${ }^{22}$

Centuries before the welfare state, relief from poverty came from charity or local organisations, which primarily meant the established Church. However, and perhaps wrongly so, the Church of England had a 'poor reputation' in this field. ${ }^{23}$ One movement is particularly linked to this perceived failure of the Anglian Church to tend to the working classes in the north of England, namely the Methodist movement. Thompson, in his praised work on the history of the English working class, writes that Methodism is the religious movement most closely associated with the industrial revolution and the working class. ${ }^{24}$ The real growth of the Methodist movement only began towards the end of the $18^{\text {th }}$ century when, in 1795, the dissenters broke free from the Anglican Church to form the independent Methodist Church. ${ }^{25}$ Methodism was "the real religion of Yorkshire", of the northern working class. ${ }^{26}$ Thompson writes that Methodist preachers became popular because they "were the poor' ${ }^{27}$ Many were lay (not ordained) preachers and came from the factories and workhouses themselves. In those contexts, well-educated Anglican priests could perhaps easily be seen as "elitist" and out of touch.

Most of the Methodist preachers were undoubtedly well-meaning and sought to bring true spiritual well-being to the working classes. However, the system of itinerant preachers was certainly open for abuse, as preachers went from house to house asking for food and money in return for their services. It may be recognised that Jesus Christ himself was an itinerant preacher. When he sent out his apostles he specifically instructed them to bring only one tunic, no money and no food. ${ }^{28}$ Let us assume that the apostles did not take advantage of the poor in Galilee, but there is certainly scope for any itinerant preacher to abuse his position and ask for more than the frugality that Jesus commanded. This was the situation in Norton $v$ Relly.

\footnotetext{
${ }^{20}$ Colin Haydon, Anti-Catholicism in Eighteenth-Century England: A Political and Social Study (Manchester University Press, 1993), 61;

21 James E Bradley, Religion, Revolution, and English Radicalism: Nonconformity in Eighteenth-Century Politics and Society (Cambridge University Press, 1990), 2

${ }^{22}$ Statute of Artificers 1563 (5 Eliz c 4); Combination Acts 1799/1800; see eg $R$ v Mawbey (1796) 6 TR 619 , 636 (Grose J); Donald Woodward, 'The Background to the Statute of Artificers: The Genesis of Labour Policy 1558-63' (1980) 33 The Economist History Review 32, 32

${ }^{23}$ Paul Langford, 'The Eighteenth Century' in Kenneth Morgan, The Oxford History of Britain (Revised edition, OUP, 2001), 436

${ }^{24}$ Edward Thompson, The Making of the English Working Class (Random House, 1963), 401

${ }^{25}$ David Hempton, Religion of the People: Methodism and Popular Religion 1750-1900 (Routledge, 1996), 9

${ }^{26}$ Langford (n 23), 484

27 Thompson (n 24), 351

${ }^{28}$ Gospel of Mark 6:8-9
} 
The case report does not include the claimant's legal arguments, but the importance of the case is highlighted by the fact that the claimant was represented by the Solicitor-General. The report includes briefly the defence arguments, which emphasised the need for religious tolerance and implored the Lord Chancellor to treat the case with 'great caution'. ${ }^{29}$ As will be evident, it is questionable whether the Lord Chancellor did so.

Mr Relly was an alleged Methodist preacher. The claimant, Miss Norton, certainly thought so. Mr Relly said he was not, merely a 'Protestant dissenting preacher' ${ }^{30}$ Lord Northington did not seem to care; he was a dissenter of some sort, and that was what mattered. ${ }^{31}$ Whatever Mr Relly's religious affiliations, he came upon Miss Norton in Leeds. The judgment does not say much about Miss Norton, other than that she was a 'maiden lady', but it is clear that she was a woman of means. ${ }^{32}$ Mr Relly convinced her to become a member of his congregation. Over the course of the following two years he obtained from her personal contributions of $£ 150$, and finally a deed of gift promising him an annuity of $£ 50$, which was secured on Miss Norton's property. ${ }^{33}$ At some point after this, Miss Norton changed her mind, and sought relief from the annuity in the Court of Chancery. Mr Relly's defence was that the money given and the annuity granted were far from gifts: they were in fact given in consideration for his time and spiritual work with Miss Norton, which she had, at least initially, found valuable.

The Lord Chancellor did begin his judgment by stressing the importance of religious tolerance and openness for those who were dissenting from the Anglican Church. However, the Lord Chancellor was clear in his mind that Mr Relly was not a genuine and honest dissenter. Rather, he was a "fanatic"; clearly one of many. The Lord Chancellor described them as preachers who,

go about in the Apostles' language, and creep into people's dwellings, deluding weak women: men who go about and diffuse their rant and warm enthusiastic notions, to the destruction not only of the temporal concerns of many of the subjects of this realm, but to the endangering their eternal welfare. ${ }^{34}$

The Lord Chancellor was not having it. Mr Relly was described in even worse terms. Having failed to establish whether or not he was a Methodist, Lord Northington had another description in mind. Mr Relly was 'a subtle sectary, who preys upon his deluded hearers, and robs them under the mask of religion; an itinerant who propagates his fanaticism even in the cold northern countries, where one should scarcely suppose that it could enter'. ${ }^{35}$ Lord Northington's description of Yorkshire is ambiguous, but seems to suggest that Yorkshiremen should be able to distinguish true Methodism from fanaticism. Yorkshire is famously well-known for its common sense approach to life. At the very least, Miss Norton should have seen that Mr Relly was not truly walking in the apostles' footsteps. The Lord Chancellor continued,

\footnotetext{
${ }^{29}$ Norton $v$ Relly (1764) 2 Eden 286, 287; 28 ER 908, 908 (defence counsel)

${ }^{30}$ Norton $v$ Relly (1764) 2 Eden 286, 287; 28 ER 908, 908 (defence counsel)

${ }^{31}$ Norton $v$ Relly (1764) 2 Eden 286, 288; 28 ER 908, 909 (Lord Northington)

${ }^{32}$ Norton $v$ Relly (1764) 2 Eden 286, 286; 28 ER 908, 908

${ }^{33}$ Norton $v$ Relly (1764) 2 Eden 286, 286; 28 ER 908, 908. The property is not defined, but given the sums involved, it would have been sizeable, such as a farm. Historical currency valuations are very difficult and are indicative at best. Using the House of Commons 1999 report on historical currency evaluation, the $£ 150$ given in gifts would amount to $£ 16,000$ and the annuity would amount to $£ 5000$, House of Commons Research Paper 99/20; this would probably be closer to at least $£ 20,000$ and $£ 8,000$ respectively in 2015 terms.

${ }^{34}$ Norton v Relly (1764) 2 Eden 286, 288; 28 ER 908, 908 (Lord Northington)

${ }^{35}$ Norton $v$ Relly (1764) 2 Eden 286, 289; 28 ER 908, 909 (Lord Northington)
} 
Does he come from Leeds to London in the ordinary way, a stage-coach? No: he must have a post-chaise, and live elegantly on the road at the plaintiff's expense; who, it appears, at different times gave to or paid for him to the amount of $£ 52,19 \mathrm{~s}$ in money, besides presents of liquor and other things. ${ }^{36}$

Lord Northington is clearly suggesting that Mr Relly lived a rather luxurious lifestyle at Miss Norton's expense. It is not the proper way. She was taken advantage of.

During the legal arguments in Nottidge $v$ Prince, counsel posited that the 'language of the judgment is violent, and not in accordance with that calm and dispassionate tone that ought to characterise a judicial decision' ${ }^{37}$ This much is true. It is clear that the Lord Chancellor was not referring to all (Methodist) dissenters, but equally it could not have been Mr Relly alone. There is nothing to suggest that Lord Northington had any particular ties to the Church of England. The strong language was likely directed at the defendant personally, as someone who had exploited religion for personal gain. However, Mr Relly's counsel said in argument that Methodism was a term 'to which ignorance and illiberality have affixed a ludicrous and contemptuous idea'. ${ }^{38}$ It suggests that Methodism was misunderstood and derided, at least in certain sections of society. The industrial revolution was making the class differences in society all the more acute, and the misunderstandings and mistrust between the classes was undoubtedly stark. It may well be that Lord Northington's judgement is a reflection of those societal attitudes, in addition to a dislike of the defendant.

The first thing of importance in this case is the relationship between Mr Relly and Miss Norton. Though not a fiduciary one in the strictest sense, it was a relationship of trust and confidence. ${ }^{39}$ Miss Norton undoubtedly trusted Mr Relly and abided by his advice. Though Mr Relly, as a poor preacher (or at least representing himself as such), might have had genuine and honest intentions behind asking for money, it was clearly done in an inappropriate manner. He exploited Miss Norton's religious affections. From the facts given (or at least the facts accepted by the Lord Chancellor), Mr Relly did not have genuine and honest intentions. It seems likely that he took advantage and in a methodical manner caused Miss Norton to become infatuated by him; as the Lord Chancellor says, the 'deed [of gift] was obtained on circumstances of the greatest fraud, imposition and misrepresentation that could be'. ${ }^{40}$ As such the parties did not approach the gift on equal footing. Mr Relly was very aware of his actions, in that the actions were planned.

The case tells us, if such a reminder is necessary, that it is unconscionable to take advantage of another person for personal gain. This is perhaps most egregious when religion is used as a pretence for obtaining favours. It should be possible to trust absolutely clergy of all denominations, not least because they have fiduciary obligations when giving spiritual advice. ${ }^{41}$ In general, the Chancery court came to recognise that the relationship between a priest and his penitent was one where undue influence would be presumed. ${ }^{42}$

Norton $v$ Relly is a fascinating insight into the early industrialised England. It brings to the front the religious tensions present in society at the time, as England tried to make sense of

\footnotetext{
${ }^{36}$ Norton v Relly (1764) 2 Eden 286, 289; 28 ER 908, 909 (Lord Northington)

${ }^{37}$ Nottidge v Prince (1860) 2 Giff 246, 263; 66 ER 103, 110 (Mr Bacon for the defendant)

${ }^{38}$ Norton $v$ Relly (1764) 2 Eden 286, 287; 28 ER 908, 908 (defence counsel)

${ }^{39}$ Hospital Products Ltd v United States Surgical Corporation [1984] HCA 64; (1984) 156 CLR 41, [30] (Gibbs CJ)

${ }^{40}$ Norton v Relly (1764) 2 Eden 286, 291; 28 ER 908, 910

${ }^{41}$ Hospital Products Ltd v United States Surgical Corporation [1984] HCA 64; (1984) 156 CLR 41, [30] (Gibbs CJ); Clark v The Corporation of the Trustees of the Roman Catholic Archdiocese of Brisbane [1996] QSC 255, [27] (Williams J); Brunninghausen v Glavanics [1999] NSWCA 199, [87]

${ }^{42}$ Erlanger $v$ The New Sombrero Phosphate Co (1878) 3 App Cas 1218 (HL), 1230 (Lord Penzance); Parfitt $v$ Lawless (1869-72) LR 2 P\&D 462, 468 (Lord Penzance)
} 
the new industrialised order. Methodism was a new religion for the poor, and became very popular with the working classes. The facts of the case also show the scope for abuse within that context. The Court of Chancery from now on kept a close eye on religious gifts.

\section{Nottidge v Prince}

This astonishing story takes place in early Victorian England. The facts centre on an infamous Christian sect or cult that was led by Henry Prince. Prince was a defrocked Anglican deacon, who had served as curate in the village of Carlinch in Somerset. It was during this ministry that Prince, together with the rector, Rev Starkey, started practicing outside the teachings of the Anglican Church. Hence, Prince was defrocked and they were removed from the parish. The two of them, with Prince in charge, founded their own Free Church.

The sect initially moved around. First it came to Suffolk, but it was expelled from their establishment by the Bishop of Ely. The sect then came to Weymouth where it was more successful in gathering followers, including some of the parties to this case. Finally, the sect settled back in Somerset, near to Carlinch, at an estate which they named Agapemone. This is the Greek term for "Abode of Love". ${ }^{43}$

Prince claimed to his followers that God spoke through him, and that, as in the days of Abraham and Moses, he was a special witness to the will of God. He would also claim to be God incarnate and that the Holy Spirit resided particularly in him. Indeed, his preaching was that the Day of Judgment had already begun. Few outside Agapemone would accept that as the truth and, indeed, it is unsurprising that Prince was defrocked. In one lawsuit concerning the sect, mentioned briefly below, Knight Bruce VC said that Prince was a 'fanatic or pseudo-fanatic preacher, styling himself "The Servant of the Lord". ${ }^{44}$ Stuart VC, in the undue influence claim, equally said that it was not clear, nor necessary to ascertain, whether Prince was a victim of his own 'disordered imagination' (a polite way of saying he was crazy) or merely adopted the persona with sinister intent. ${ }^{45}$

Agapemone was a controversial place and was not well-liked by contemporary society. It is not clear how much is true and how much is idle gossip and speculation by a shocked and outraged Victorian society. The most notorious allegations were those of improper sexual conduct between Prince and female congregants. ${ }^{46}$ Banman, in a study of contemporary print media, notes that Prince and Agapemone were heavily criticised in the press. There were numerous lawsuits between spouses and converts over money granted to Prince (Nottidge being one); Prince was physically attacked by locals, and again, in the papers there were repeated allegations of improper social conduct between the sect leaders and the female followers. ${ }^{47}$ The allegation was that Prince took "spiritual brides", and engaged in sexual acts for spiritual purposes. It is, of course, a serious allegation. ${ }^{48}$ In a literary review of WWI stories, it is found that the term "agapemone" had entered popular culture as referring to something sexual, a testament to the sect. ${ }^{49}$ Agapemone closed in 1956 when the last remaining female congregant died.

\footnotetext{
${ }^{43}$ Sol Steinmetz, Semantic Antics: How and Why Words Change Meaning (Random House, 2008), 2

${ }^{44}$ Thomas $v$ Roberts (1850) 3 De Gex \& Smale 758, 765; 64 ER 693, 696 (Knight Bruce VC)

${ }^{45}$ Nottidge v Prince (1860) 2 Giff 246, 269; 66 ER 103, 113 (Stuart VC)

46 Joseph Bristow, 'Respecting Respectability: 'Victorian Sexuality' and the Copulatory Imagination - The Making of Victorian Sexuality by Michael Mason' (1996) 41 History Workshop Journal 286, 289

47 Christina Banman, 'The Study of Religion: Nineteenth Century Sources and Twentieth Century Misconceptions' (1989) 1 Method \& Theory in the Study of Religion 160, 167

${ }^{48}$ See, for instance, Roger Evans, Somerset Tales of Mystery and Murder (Countryside Books, 2004), 28

49 Terry Phillips, 'The Discourse of the Vampire in First World War Writing' in Peter Day (ed), Vampires: Myths and Metaphors of Enduring Evil (Editions Rodopi, 2006), 68
} 
It was around 1842 that Prince first came into contract with the Nottidge family. The Nottidges' were a 'Suffolk family, with wealth in banking and silk milling and numerous connections with the Anglican Church' ${ }^{50}$ By all accounts, they were respectable middleclass. There were five sisters, of whom four joined the sect. Agnes, Harriet and Clara were the first to join Prince. ${ }^{51}$ At Prince's suggestion or request (communicated as the will of God, which of course could not be disobeyed) they married three of Prince's male followers. The ceremony took place in Swansea in July 1845. Agnes married George Thomas, which eventually gave rise to a custody dispute before the Court of Chancery.

The custody dispute is worth mentioning since the facts are also the starting point to the undue influence claim. As said, Agnes married George in Swansea. This was before Prince had purchased Agapemone and was still residing in Weymouth. Prince obtained various monies from the Nottidge sisters as part of the marriages and also received contributions from elsewhere. With that money he eventually obtained the house and farmland that would become Agapemone.

There was some strife between George and Agnes. In December 1845, Agnes learnt that Prince was trying to persuade her sister Louisa to join the sect. Agnes composed a letter to Louisa trying to dissuade her. From the facts as stated in the two cases, it is not clear why Agnes was writing this letter, but obviously she had concerns. A member of the sect happened to see the letter and showed it to Prince. George also learnt of it. Prince and George were both unhappy. To make a long story short, George asked Agnes to leave the community. ${ }^{52}$ Prince forbade her from going back to her mother (perhaps so that she could not further dissuade Louisa). Agnes in the end settled with George's mother. Agnes was at the time pregnant with a son, who was born when Agnes had moved in with Mrs Thomas. At first, George showed little interest in the son, apparently influenced by Prince. Agnes's petition to the Court of Chancery was that Agnes and Mrs Thomas be appointed guardians of the son; however, during the hearing George also cross-petitioned for guardianship as the son's father.

Knight Bruce VC heard the claim. The (seemingly foregone) conclusion was that George had no right of custody over his son. The Vice Chancellor said that 'God forbid that I should be accessory to condemning any child to such a state of probable debasement' ${ }^{53}$ In a later commentary, Jackson referred to the judgment as a 'capital example of caustic judicial humour' ${ }^{54}$ The judgment painted a very clear picture of how society at large viewed the sect.

The undue influence claim was brought 10 years later, in 1860. As noted, this story begins in 1845. Prince was trying to get Louisa to join the community. Agnes wrote to dissuade her. Nonetheless, in early 1846 Louisa joined the sect (a somewhat surprising decision as it was around the same time her sister was expelled). Her mother, Mrs Nottidge, was not impressed, having already seen three of her other daughters get married into the sect. Thus, one of Louisa's brothers, Rev Edmund, and a brother-in-law, Mr Ripley, together with a police officer, went and (in the end forcibly) removed Louisa from Agapemone. At the brother-inlaw's house, Louisa declared her firm desire to return and remain with Prince, who, she explained, "was the Almighty in the form of a man, and had the power of conferring immortality'. ${ }^{55}$ Louisa was, based on these beliefs, assessed by a doctor who certified her as insane. She was placed in an asylum.

\footnotetext{
${ }^{50}$ Joshua John Schwieso, "Religious Fanaticism” and Wrongful Confinement in Victorian England: The Affair of Louisa Nottidge' (1996) 10 Social History of Medicine 159, 160

${ }^{51}$ Ibid, 161

52 Thomas $v$ Roberts (1850) 3 De Gex \& Smale 758, 760; 64 ER 693, 694

${ }^{53}$ Thomas $v$ Roberts (1850) 3 De Gex \& Smale 758, 773; 64 ER 693, 699 (Knight Bruce VC)

${ }^{54}$ JH Jackson, 'The Religious Education of Children' (1896) 12 Law Quarterly Review 379, 380

${ }^{55}$ Nottidge v Prince (1860) 2 Giff 246, 246; 66 ER 103, 103 (headnote)
} 
After a few years, Louisa successfully appealed to the Lunacy Commission and was released. The Commission found that she was capable of looking after herself; it was the start of the general legal view that only people posing harm to themselves or others should be sectioned. Louisa's story became something of a cause celebre, as it helped fuel the Victorian fascination with mental health. ${ }^{56}$ After her release, Louisa successfully claimed damages for false imprisonment against her brother and compensation for expenses from the asylum. Louisa returned to Agapemone, where she died intestate in 1858.

The administrator of her estate was one of her brothers, Ralph Nottidge. As administrator, he brought a claim before the Court of Chancery to set aside two annuities (worth nearly $£ 6000$ ) and to reclaim dividends already paid since 1845 . The claim alleged that the gifts had been granted through undue influence on the part of Prince. The case was heard by Stuart VC. Unsurprisingly, Stuart VC allowed the claim. In judgment, he said that Prince had 'exercised a powerful and undue dominion over the mind of Miss Nottidge' by claiming to be the Almighty. It was clear that 'by falsely and blasphemously pretending that he had a direct divine mission, [Prince] imposed on these weak women and obtained a gift of the whole of their fortunes'. ${ }^{57}$ The court took a clear view that Prince was in the wrong and prayed on weak-willed women. One can only imagine Stuart VC's view of Prince, who in the witness box had repeated his claims that he was God incarnate.

The judgment continued by discussing the rather delicate question of the propriety of setting aside what were, in effect, voluntary dispositions, though given under a religious belief or delusion. It highlights they very difficult task of drawing a line between genuine religious belief which may lead to charitable donations, and donations which appear to have been freely given but were in fact the product of some unconscionable imposition or context. The answer in this case was rather clear, even if one removes possible societal biases. Stuart VC said that the 'grossness of the imposture in the present case has put it far beyond mere spiritual influence'. ${ }^{58}$ This is not the case of a priest giving suggestions for donations to a congregation or even encouraging the devout to donate. Prince built up a community based on his insistence that he directly spoke the will of God. Stuart VC is right in saying that is defies rational logic why anyone would believe and follow such a cult leader, but historical evidence shows a multitude of sects of a similar kind. There is a strong need for the law to vitiate gifts given in such circumstances. ${ }^{59}$ Stuart VC explains the policy.

'The strength of religious influence is far beyond that of gratitude to a guardian, trustee or attorney, and the same ground of public utility which requires this Court to guard against such influences has its most important application to that influence which is the strongest' ${ }^{60}$

This theme will be returned to below when discussing Allcard $v$ Skinner. The religious context is rather unique in how it expects obedience without too much question, though submission to the institution is generally voluntary. It poses a very difficult legal question.

The Nottidge litigations are fascinating. The facts of the cases give real insight into Victorian society, and the views and moralities of the common populace. The story has it all - religious delusion and fanaticism, wrongful detention in asylums, kidnapping, sex, and family dramas worthy of any soap. It is absolutely correct that the undue influence claim

\footnotetext{
56 Schwieso (n 50), 167. Louisa Nottidge's story apparently inspired Wilkie Collins' celebrated mystery novel, The Woman in White (1859).

${ }^{57}$ Nottidge v Prince (1860) 2 Giff 246, 268; 66 ER 103, 112 (Stuart VC)

${ }^{58}$ Nottidge $v$ Prince (1860) 2 Giff 246, 269; 66 ER 103, 113 (Stuart VC)

${ }^{59}$ Nottidge v Prince (1860) 2 Giff 246, 267; 66 ER 103, 112 (Stuart VC)

${ }^{60}$ Nottidge $v$ Prince (1860) 2 Giff 246, 270; 66 ER 103, 113 (Stuart VC)
} 
succeeded. On any level, it would be unconscionable for Prince to retain the money. This is a case where he (not necessarily with sinister intent) lead weak and suggestible people to give him large sums of money by the pretence (or delusional belief) that he spoke God's direct word and could grant immortality. (One can only imagine the shock in the community when Prince himself died, and it is remarkable that his successor Smyth-Pigott managed to keep the sect running). The unconscionability takes many forms, but in particular it is the abuse of power and sheer exploitation of a position of religious influence which makes the gifts tainted, meaning they cannot be retained.

\section{Allcard v Skinner}

Allcard $v$ Skinner remains a key case in the law of undue influence. The facts bear similarities to both Norton and Nottidge. The case also continues to explore changing social values in mid-Victorian England. In particular, the case highlights the struggle for women to be recognised as free and independent from the paternalist family-structures that still prevailed.

In the desire to be free from the men who ruled the family, a number of women in Victorian England chose to join sisterhoods, which were akin to Catholic convents. These sisterhoods were administered by the Church of England. The Agapemone sect caused outrage; these sisterhoods similarly attracted much criticism from many parts of society. The concern seemed to be three-fold; societal concern over the breakdown of families and a loss of paternal authority, the doubt and disbelief that women were able to run their own communities, and an Anglican religious concern that these sisterhoods seemed to be suspiciously similar to Catholic practices.

The case featured a young woman, Miss Allcard, who joined one of these Anglican sisterhoods. It was called the Sisters of the Poor, and it operated in Finsbury in London. Miss Allcard wanted to do something good with her life, and she sought the counsel of her priest, Reverend Nihill. Nihill was the vicar at St Michael's in Shoreditch, East London since 1865. ${ }^{61} \mathrm{He}$ was also associated with St Mark's in Finsbury, from which the Sisters of the Poor operated. ${ }^{62}$ The historical facts are not entirely clear on when he was where. Miss Skinner, the defendant, was the Mother Superior of the sisterhood. Nihill suggested to Miss Allcard that she could join the Sisters of the Poor, which she eventually did.

Before looking further at Miss Allcard's case, it is convenient to consider Nihill. As said, there were many similar sisterhoods in London, and they caused much concern in contemporary society. Kollar, in his study of Anglican sisterhoods in London during the mid$19^{\text {th }}$ century, introduces us to Nihill already in 1867. This is three years before Miss Allcard formally joined the Sisters of the Poor (though Miss Allcard first became associated with the sisterhood in 1868, a year after these events). At the time in 1867, Archibald Tait was Bishop of London, and the next year he would be translated to Canterbury.

The uncle of a Miss Westbrook complained to the Bishop of "some undue, improper and sinister meanor [which] have been adopted to influence the gentle, yielding and rather weak mind of Miss Westbrook by the authorities of St Michael and All Angels." ${ }^{\prime \prime 3}$ Several other family members similarly expressed concern about how Miss Westbrook was treated, arguing that she was being pressured into joining. A particular concern was that Nihill and the sisterhood wanted Miss Westbrook's inheritance, which was noticeable. ${ }^{64}$ Bishop Tait wrote to Nihill raising these concerns, a letter which included the phrase, "I shall be glad to hear

\footnotetext{
${ }^{61}$ Rene Kollar, 'A Death in the Family: Bishop Archibald Campbell Tait, the Rights of Parents, and Anglican Sisterhoods in the Diocese of London' (2003) 27 Journal of Religious History 198, 210

${ }^{62}$ Allcard v Skinner (1887) 36 Ch D 145, 155 (Kekewich J)

${ }^{63}$ Kollar (n 61), 210; see Lambeth Palace Library, Tait Papers, Vol. 148, Banting to Tait, 3 October 1867.

${ }^{64}$ Kollar (n 61), 211
} 
from you that you are doing what you can to prevent any undue influence from being exercised over her by those connected with the sisterhood in question". ${ }^{65}$ There was no response from Nihill, but Miss Westbrook did not enter the sisterhood.

This event is interesting for two reasons. Firstly, it raises the importance of family decisionmaking in Victorian society and how closely that was guarded by the Bishops who oversaw the Anglican sisterhoods. Bishop Tait came to insist on paternal consent before any women was permitted to join a sisterhood. ${ }^{66}$ In 1870 when Miss Allcard joined, Bishop Tait had been elevated to Canterbury. It is not clear how his successor in London saw the idea of parental consent. In the first instance, Kekewich J noted that Miss Allcard's mother and brother stated their objections to her joining the sisterhood (her father being deceased). ${ }^{67}$ By all accounts, Miss Allcard was permitted to join without any parental consent, suggesting that Tait's successor in London did not insist on such consent being given. The second reason why Miss Westbrook's story is of interest is that Miss Allcard was not the first to complain of the practices of Nihill. It gives greater historical validity to Miss Allcard's complaint.

Miss Allcard formally joined the sisterhood in 1870 as a novitiate. A year later, in 1871, she took final vows. This included a vow of poverty. She was not permitted to have property of her own. ${ }^{68}$ She was given the choice of handing over her property to her family, or to the poor, or to Miss Skinner to be held on trust for the use of the sisterhood. The documents provided to Miss Allcard clearly favoured the third option, of giving the property to the sisterhood. The rules also stated that if the sister was to leave the sisterhood, she would not be able to ask for her property back. Miss Allcard chose the third option and also made a will in favour of the sisterhood.

Miss Allcard was a member of the Sisterhood for eight years. During those years, she handed over two cheques totalling $£ 1050$ and various shares totalling about $£ 5,800$. Miss Allcard was involved in spending some of that money on various projects in London. She gave personal consent to all those projects, and as a sister, willing participated in the Sisterhood's work. In 1879 Miss Allcard decided to leave in order to convert to become a Catholic. In 1885, six years later, Miss Allcard brought a claim before the Chancery Division to reclaim her property, arguing, amongst other things, that the property had been handed over after undue influence on the part of Miss Skinner, and to an extent, Nihill.

Once Miss Allcard had joined the sisterhood as a postulant, whilst free to leave at any time, she came under the direct influence of Miss Skinner. Kekewich J calls it an 'influence which is known to be powerful and seldom loses or is allowed to lose its hold' ${ }^{69}$ Kekewich $\mathrm{J}$ also states that whilst there is no direct evidence suggesting that either Miss Skinner or Nihill directly influenced the content of Miss Allcard's will or her subsequent decision to grant gifts to the sisterhood, he held that Miss Allcard's decisions were 'the natural result of the convent influence' ${ }^{70}$ Again, like with Norton $v$ Relly above, it is clear that the nature of the relationship between the parties is of great importance. The balance of power between the parties was distinctly skewed, and it is clear that Miss Skinner and Nihill had a position of great power and influence. That is not to say that they used it with sinister intent, but it led to a particular ethos within the sisterhood. In discussing the law and the facts, Kekewich J states as much.

\footnotetext{
${ }^{65}$ Kollar (n 61), 212; see Lambeth Palace Library, Tait Papers, Vol. 148, Tait to Nihill, 11 November 1867

${ }^{66}$ Kollar (n 61), 205

${ }^{67}$ Allcard v Skinner (1887) 36 Ch D 145, 156 (Kekewich J)

${ }^{68}$ As with Norton $v$ Relly above, the vow of poverty, which is present in all religious orders, stems from Jesus being a preacher to the poor; see eg Gospel of Mark 6:8-9

${ }^{69}$ Allcard v Skinner (1887) 36 Ch D 145, 156 (Kekewich J)

${ }^{70}$ Allcard v Skinner (1887) 36 Ch D 145, 156 (Kekewich J)
} 
The more powerful influence or the weaker patient alike evokes a stronger application of the safeguard, and there can be no case more urgently requiring it than one of the influence of a priest, director, or mother superior of a convent, on an emotional woman, residing within the convent walls, and subject to its discipline. ${ }^{71}$

Undue influence is dependent on the particular facts of the relationship, the nature of the influence exercised, and the state of mind on the influenced party. The context of a religious sisterhood is important here; the judge continues by noting that 'religious influence is the most subtle of all', and that there was no need to find evidence of direct and overt pressure. ${ }^{72}$ Lindley LJ repeats the reference to 'subtle', continuing by saying that 'religious influence is the most dangerous and the most powerful'. ${ }^{73}$ For instance, Miss Allcard's will (leaving all her property to the sisterhood) was in a service placed upon the altar and consecrated; Lindley LJ considered it part of the process of impressing on Miss Allcard the irrevocable nature of the will. ${ }^{74}$ Equally, there appears to have been several occasions on which Miss Allcard wanted to leave the sisterhood but was, at least by spiritual pressure, prevented from doing so by Miss Skinner. ${ }^{75}$ Kekewich $\mathrm{J}$ continues by speaking of the importance of "independent advice" before any gifts are made, especially by members of a closed religious community. ${ }^{76}$ In the end, however, the claim was dismissed by Kekewich $\mathrm{J}$ on the basis that undue influence was not present, and Miss Allcard had made the initial promise to give her money to the sisterhood before she formally joined, and when she still had the benefit of external advice from her family. ${ }^{77}$ It is this conclusion (focusing on when Miss Allcard made the initial promise, rather than the conditions at the time the actual transfers were made) that was overturned in the Court of Appeal. ${ }^{78}$

The appeal to the Court of Appeal concerned purely two sets of shares which Miss Skinner still had control over; Miss Allcard did not pursue any compensation for the money given and spent by the sisterhood. As noted in the second section, the Court of Appeal clarified the modern rules on undue influence and divided the doctrine into its two classes. ${ }^{79}$ The facts in Allcard did not lend themselves to actual undue influence: there had been no direct pressure applied. ${ }^{80}$ Miss Allcard made her initial promised before formally joining the sisterhood, when she was still in regular contact with her family, and after joining she was still at all times in contact with her brother (albeit at Miss Skinner, as the mother superior, read the brother's letters). One can see, however, how close the facts in Allcard were to becoming actual undue influence.

Miss Allcard's case instead came within the second type (and as noted above, there is now in the law a rebuttable presumption in relationships between priests and congregants). ${ }^{81}$ Lindley LJ states clearly that Miss Allcard joined the sisterhood out of her own free will, and that she also voluntarily submitted to the expectations to leave her property to the sisterhood. ${ }^{82}$ She was legally entitled to make the gifts that she made. It places great complexity on the case.

\footnotetext{
${ }^{71}$ Allcard v Skinner (1887) 36 Ch D 145, 158 (Kekewich J)

${ }^{72}$ Allcard v Skinner (1887) 36 Ch D 145, 158 (Kekewich J)

${ }^{73}$ Allcard v Skinner (1887) 36 Ch D 145, 183 (Lindley LJ)

${ }^{74}$ Allcard v Skinner (1887) 36 Ch D 145, 176 (Lindley LJ)

${ }^{75}$ Allcard $v$ Skinner (1887) 36 Ch D 145, 176 (Lindley LJ)

${ }^{76}$ Allcard v Skinner (1887) 36 Ch D 145, 159 (Kekewich J)

${ }^{77}$ Allcard v Skinner (1887) 36 Ch D 145, 168 (Kekewich J)

${ }^{78}$ Allcard v Skinner (1887) 36 Ch D 145, 191 (Bowen LJ)

${ }^{79}$ Allcard v Skinner (1887) 36 Ch D 145, 171 (Cotton LJ)

${ }^{80}$ Allcard v Skinner (1887) 36 Ch D 145, 181 (Lindley LJ)

${ }^{81}$ Allcard v Skinner (1887) 36 Ch D 145, 171 (Cotton LJ)

${ }^{82}$ Allcard v Skinner (1887) 36 Ch D 145, 178 (Lindley LJ)
} 
Bowen LJ resolves the problem as part of the persistent divide between the common law and equity. The common law, being claimant-focused, would clearly say that Miss Allcard freely joined (there was no duress) and had mental competence; hence there is no relief. Equity, however, is defendant-focused. Bowen LJ says that undue influence is "not a limitation placed on the action of the donor; it is a fetter placed upon the conscience of the recipient of the gift, and one which arises out of public policy and fair play'. ${ }^{83}$ As such, we are not looking to whether Miss Allcard did something right or wrong, or whether she was legally entitled to do what she did. The only pertinent question is whether it is conscionable for the sisterhood to retain the gift.

What caused great concern to the court was the rule of the sisterhood which prevented a member from seeking outside advice without the prior consent of Miss Skinner as the Mother Superior. ${ }^{84}$ The wording and ethos of such a rule would make it most difficult to rebut any presumption of undue influence, especially so since Miss Allcard lived within a closed community. Lindley LJ could not find any evidence of undue pressure or deceit being practiced on Miss Allcard, and all the money given was in fact used in good faith for the sisterhood's projects. ${ }^{85}$ There was no wrongdoing, but still it would be unconscionable to allow the Sisterhood to retain the property.

Lindley LJ thus allows the claim for presumed undue influence, primarily on the basis that Miss Allcard could not seek independent advice with Miss Skinner's prior consent. ${ }^{86}$ Although Miss Allcard communicated with her brother, this was perhaps not the same thing as seeking proper advice, and certainly not independent since Miss Skinner read all the letters. There is no suggestion of actual wrongdoing on the part of Miss Skinner or Nihill; the issue is the ethos created by the rule limiting access to independent advice. The proposed remedy was to return to Miss Allcard the stocks still held by Miss Skinner; there was no suggestion by the majority that Miss Allcard be allowed equitable compensation for the full amount given to the sisterhood. Equitable rescission 'can be granted upon terms', and it is not about strictly restoring the parties to their earlier position. ${ }^{87}$ The proposed remedy in Allcard $v$ Skinner, of Miss Allcard receiving the money that Miss Skinner had not yet spent, was appropriate - there was no need for Miss Skinner to personally compensate Miss Allcard for all the money given and already spent. ${ }^{88}$ The situation would likely have been different if Miss Skinner had spent the money for personal gain. However, in the end, the majority refused any relief on the basis of laches. ${ }^{89}$

Allcard $v$ Skinner tells us much about undue influence. A close reading of the judgment, coupled with an understanding of the facts and context, tells us about the role of the relative balance of power within a relationship, and how covert pressure quickly can become unconscionable. The core of the appellate judgment turns on the fact that Miss Allcard was not permitted to seek outside, independent advice at the time of making the individual gifts. Whilst Kekewich $\mathbf{J}$ in the first instance held that she had outside advice when making the initial promise on joining the sisterhood, and Court of Appeal held that the crucial issue is the availability of advice when making the actual transfer. Promises are not binding and potential donors may change their minds. But how can a person change her mind if no outside advice

\footnotetext{
${ }^{83}$ Allcard $v$ Skinner (1887) 36 Ch D 145, 190 (Bowen LJ); see also Richard Hedlund, 'The Theological Foudantions of Equity's Conscience' (2015) 4 Oxford Journal of Law and Religion 119, 122-126

${ }^{84}$ Allcard v Skinner (1887) 36 Ch D 145, 178 (Lindley LJ)

${ }^{85}$ Allcard v Skinner (1887) 36 Ch D 145, 179 (Lindley LJ)

${ }^{86}$ Allcard v Skinner (1887) 36 Ch D 145, 184 (Lindley LJ)

${ }^{87}$ Pauline Ridge, 'The Equitable Doctrine of Undue Influence Considered in the Context of Spiritual Influence and Religious Faith: Allcard v Skinner Revisited in Australia' (2003) 26 University of New South Wales Law Journal 66, 78

${ }^{88}$ Ibid, 78

${ }^{89}$ Allcard v Skinner (1887) 36 Ch D 145, 186 (Lindley LJ); 193 (Bowen LJ)
} 
or opinion may be heard? To a person who lives within closed walls, hearing daily only the one opinion of the donee, it is clear that the donee cannot conscionably retain any gifts.

\section{Undue Influence and Religious Institutions in the Modern Law}

These three cases, amongst others, laid the foundation of the modern law on undue influence. The facts help us to see how easily a religious institution can become liable for undue influence. The judgments, in particular the latter two, demonstrate remarkable psychological insight into the effects that religious belief and devotion can have on a person, and consequently how easily that person can be manipulated. It begs the important question of how one can be sure that gifts to religious institutions are freely given.

These cases each demonstrate a situation where, at least at first glance, the gifts were freely given. Three women, for different reasons, voluntarily joined a religious community. There were no threats of violence or harm. This line of reasoning, as noted by Bowen LJ, leads us down the garden path. Equity is not very much concerned with the actions of the claimants; actions which were lawful and voluntary. The interest is with the defendants. Can they, in good conscience, retain the gifts? In each of the three cases, the answer is no. The reason is that the defendants all encouraged the claimants to join; once they had joined they were hooked. The unconscionability comes in principle from the fact that the defendants created an environment, or an ethos, in which the gift-giving became, in effect, an emotional and religious necessity.

The sense that gift-giving is an emotional necessity is perhaps most obvious in religious contexts. Religious leaders, preachers, and sect and cult organisers can authoritatively claim that any gift is necessary because it is God's will. Once that statement is made, most devotees would have a negative emotional reaction if they decided not to grant the gift. They would feel as if they had somehow failed. This line of reasoning is evident in the judgments of each of the Victorian judges. It is important that religious institutions do not actively create any environment in which granting sizable donations is a religious imperative. This problem continues to arise today, such as in the contexts of proselytising and tithing.

Proselytising is the process by which a religious group attempts to convert new members. Christian proselytising has a basis in the Gospel, where the resurrected Christ instructs his apostles to 'make disciples of all nations'. ${ }^{90}$ The manner in which such attempts as conversion takes place can be problematic. The matter has been discussed by the European Court of Human Rights. Within Article 9, which protects freedom of religion, the Court has drawn a distinction between spreading the message of a religious group and improper proselytising', which the Court said carried the risk of 'exerting improper pressure on people in distress or in need'. ${ }^{91}$ English courts have also warned about the dangers of improper proselytising, including to the extent of granting injunctions to prohibit intrusive proselytising on the grounds of nuisance and harassment. ${ }^{92}$

Tithing is, in effect, a mandatory donation (today usually of money) to the religious institution. Tithing has its origin in the laws of the Old Testament. ${ }^{93}$ The purpose of tithing was to give food and drink and other essentials to the Levites (the religious officials), the poor, orphans, widows, and foreigners. ${ }^{94}$ In modern times, tithing has been misunderstood as

\footnotetext{
${ }^{90}$ Matthew 28:19 (NRSVACE)

${ }^{91}$ Kokkinakis v Greece (A/260-A) (1994) 17 EHHR 397, [48]; Lautsi v Italy (30814/06) (2012) 54 EHRR 3 , [62]

${ }^{92}$ Williamson v Secretary of State for Education [2003] QB 1300, [167] (Rix LJ); The Church of Jesus Christ of the Latter Day Saints v Price [2004] EWHC 3245 (QB), [210] (Beatson J)

${ }^{93}$ Deuteronomy 14:22-23

${ }^{94}$ Deuteronomy 26:12
} 
a financial requirement, though the Old Testament is clear that what was sought was agrarian tithing, i.e. offering up the fruits of the land. ${ }^{95}$ The law of the Old Testament does not mandate the size of all tithes, but states that one tenths of animals are 'holy to the Lord' ${ }^{96}$ Today it is often suggested that $10 \%$ is a mandatory figure for tithes, which, apart from the animal passage in Leviticus, is generally traced to the pre-law event when Abram (Abraham) gave one-tenth of war spoils to King Melchizedek. ${ }^{97}$ Interestingly, the medieval jurist St German suggested that tithing was a "law of God" but that the size of the tithe was regulated by human laws. ${ }^{98}$ The current controversy about tithing was explored in an in-depth news article by Suzanne Sataline in the Wall Street Journal. ${ }^{99}$ Some religious institutions are highly in favour of tithing, and indeed some, including the Mormons, levy a mandatory tithe, whereas other religious institutions are more reluctant and prefer to ask for voluntary donations. By way of an example, the Roman Catholic Code of Canon Law states that the 'faithful are obliged' to provide material assistance and that the Bishops can, 'in an appropriate manner' remind the faithful of this obligation. ${ }^{100}$ The drafting of the Code (consider canons 1259 to 1261) seem to strive for an appropriate balance between insisting on material assistance from its members whilst at the same time avoiding undue imposition and pressure.

Undue influence appears as a potential factor for any donation given after either proselytising or a religious institution calling for a tithe on religious grounds. This does not mean that religious institutions can never ask for donations, seek new members, or call for tithes. What is does suggest is that religious institutions must recognise the effect of religious devotion, recognise the risk of undue influence, and proceed with due caution.

The cases also turn on the psychological profiles of the different parties. Norton $v$ Relly and particularly Nottidge $v$ Prince demonstrate some form of psychological imbalance between the parties. The cases suggest that the women were "weak-willed" and thus perhaps gullible and easily suggestible. Of course, it is not possible to say if that is true or if that is a prejudice on the part of the judges. However, sects and others do prey on the weak-willed, on the desperate, and the emotionally vulnerable. It is easy, no doubt, to win their loyalty with the promise of divine and eternal love. Research suggests that belonging to a sect is 'a possible solution to existential difficulties by individuals who, in periods of crisis, have a more acute feeling of disorientation and solitude and who feel that the institutions and society structures cannot adequately fulfil their needs' ${ }^{101}$ Evidence shows that sects do not have a higher proportion of mental illness, and one should not immediately equate mental illness and emotional vulnerability. ${ }^{102}$ It is a tragic reality even today that people feel sad, lonely, depressed, and rejected from the social norms. There is an easily exploitable longing for acceptance and belonging. As such, sects are premised on the 'capacity of a charismatic leader to exert a dominative force', and indeed this 'dynamic interrelationship' between the vulnerable follower and the charismatic leader is vital. ${ }^{103}$ Membership, namely devotion to

\footnotetext{
${ }^{95}$ Leviticus 27:30; Nehemiah 13:12-13

${ }^{96}$ Leviticus 27:32

${ }^{97}$ Genesis 14:20

${ }^{98}$ Mark Walters, 'St German on Reason and Parliamentary Sovereignty’ (2003) 62 Cambridge Law Journal 335, 350

${ }^{99}$ Suzanne Sataline, 'The Backlash Against Tithing', Wall Street Journal, Nov 23, 2007

${ }^{100}$ Roman Catholic Code of Canon Law, 1983, Can 221, Can $1261 \S 2$

${ }^{101}$ Iginia Mancinelli MD, Anna Comparelli MD, Paolo Girardi MD and Roberto Taterelli MD, 'Mass Suicide: Historical and Psychodynamic Considerations’ (2002) 32 Suicide and Life-Threatening Behaviour 91, 96

102 Simon Dein and Roland Littlewood, 'Apocalyptic Suicide' (2000) 3 Mental Health, Religion and Culture 109,110

${ }^{103}$ Mancinelli (n 101), 96
} 
the leader, can be taken to the extreme, with well-known instances of mass suicide within sects. ${ }^{104}$

As the Victorian judgments presciently do, the law should openly engage with these psychological factors that may impact on the validity of transactions to organisations. Joining a group, especially living behind walls as Miss Nottidge and Miss Allcard did, carries with it psychological implications: namely the group, or pack, mentality. The psychologist Carl Gustav Jung writes that once in a crowd it is easy for an individual to lose individuality and to go along with group decisions even when the person knows that they are wrong or immoral. ${ }^{105}$ In this instance, once Miss Nottidge had joined the sect (which in itself speaks to emotional immaturity and suggestibility), she was no doubt lost to the crowd. Indeed, Jung continues by saying that emotions can easily lead to the unconscious taking control, and then 'very strange ideas indeed can take possession of otherwise healthy people'. ${ }^{106}$ It is a psychological explanation as to why people sometimes act "out of character". In an Australian case, Bryson $\mathbf{J}$ said that commonly 'persons claiming this relief have made gross errors of judgment, obvious to any objective outsider'. ${ }^{107}$ It is important that the law recognises that, psychologically, sometimes people can fall under a spell and that this should not, in and off itself, be a bar to relief.

Undue influence in the context of gifts given to religious institutions continue to arise. The courts still struggle to draw the line between gifts freely given out of religious devotion and gifts procured by unconscionably pressure. It shows that it is important to revisit the old authorities to see what application they have today. Two Australian decisions will be considered briefly to illustrate the modern application of undue influence to gifts given to religious institutions.

The first is McCulloch v Fern. Mrs Fern was the founder and leader of a religious sect, based in Wapengo in New South Wales. It was an off-shoot of the international The Church Universal and Triumphant. Mrs McCulloch was a 'devout' follower. ${ }^{108}$ She gave \$93,000AUS to the sect. Mrs McCulloch at the time was living at the sect's farm and was very clearly pressured into giving the gift. By any standard, it would be unconscionable for the sect to retain the money. ${ }^{109}$ The judge held that Mrs Fern applied religious pressure on Mrs McCulloch in order to procure the gift. The judge wrote that 'Mrs Fern said to Mrs McCulloch words to the effect "the payment of the money is part of the divine plan. The payment is necessary in order to anchor the light on the farm. It is a requirement of the Master. Without the payment of the money the Ruby Ray Order could not be anchored here at the farm ... All our divine plans will fail without the payment of this money"". ${ }^{110}$ The religious pressure could hardly become more clear and overt. Any suggestions of "you must because it is God's will" are inherently suspect and must be treated cautiously. The judge also engaged with the psychological dominance that Mrs Fern had over Mrs McCulloch. The judge wrote of Mrs Fern saying, it 'is clear that she is an intense and forceful person, capable of demonstrating charm as well as severity. She speaks fluently and with conviction. It is

\footnotetext{
${ }^{104}$ Mancinelli (n 101), 95

105 Carl Gustav Jung, The Archetypes and the Collective Unconscious ( $2^{\text {nd }}$ edn, Routledge, 1959, tenth printing 1991), 126. This has consequences for the criminal law doctrine of "common purpose" or "joint enterprise" where the law has been criticised, consider $R v$ Gnago [2012] 2 WLR 17; $R$ v Powell (Anthony) and English [1999] 1 AC 1.

106 Jung (n 105), 278

${ }^{107}$ Hartigan $v$ International Society for Krishna Consciousness Inc [2002] NSWSC 810, [28] (Bryson J)

${ }^{108}$ McCulloch v Fern [2001] NSWSC 406, [2] (Palmer J)

${ }^{109}$ McCulloch v Fern [2001] NSWSC 406, [114] (Palmer J)

${ }^{110}$ Mc Culloch v Fern [2001] NSWSC 406, [52] (Palmer J)
} 
easy to understand how such a personality would dominate a person as vulnerable as Mrs McCulloch'. ${ }^{111}$ Mrs McCulloch was the contrary.

'Mrs McCulloch was frail and in poor health. She had had breast cancer, she had an ongoing heart condition, she was suffering from shingles. She was under strain from a physically taxing "initiation" which involved her making fourteen "stations of the cross" on the property. She was isolated from her husband; she was not permitted free communication with her children or anyone else inside or outside the small community of Mrs Fern's followers living on the property. She was of nervous disposition and appeared to be worried and distressed'. ${ }^{112}$

The evidence of vulnerability is very clear. It is clear from the evidence that Mrs Fern could not justify the payment.

The second Australian case is Hartigan v Krishna Consciousness. ${ }^{113}$ Mrs Hartigan gifted her farm to the local Krishna group; who promptly sold it to pay off their own debts. There was a factual dispute over how much Mrs Hartigan knew about their intentions, and about the promises that may have been made to Mrs Hartigan by the group to rehouse Mrs Hartigan and her family on the Krishna farm. The defendants did not sufficiently advice and inform Mrs Hartigan about the implications of the gift nor did she seek independent advice. Bryson J said that the gift "was an enormity, quite outside the range of benefactions which a person could be expected to make either according to ordinary community standards of regard for one's own interest or according to the philosophy taught by the Krishna Consciousness Movement'. ${ }^{114}$ Because this, especially the second part, was not communicated to Mrs Hartigan even though the defendants did or should have known it was well beyond that the Krishna movement expected, 'it would be altogether unconscionable for the defendant to rely on the validity of the donation'. ${ }^{115}$ Relief was granted and Mrs Hartigan was awarded compensation in the sum of the value of the farm she had gifted to the Krishna group.

The three cases considered above laid the foundations of the law in this area. They give a fascinating insight into society at the time, from the mid- $18^{\text {th }}$ century to the latter part of Victorian England. This was a time of great changes in society; as the working class was emerging and as women were seeking their independence from rigid family structures. In addition to laying down the legal principles of undue influence, those judgments played their part in facilitating this social change through adjudicating the consequences from these developments. It is clear that undue influence has a continuing role to play in regulating gifts to religious groups and institutions. The courts must be mindful of how easily a person can become emotionally and spiritually attached to a religious group and similarly how easy it is for an unscrupulous or fraudulent person to exploit that mentality. The courts must also remain mindful of the psychological factors that can be at play, and any emotional imbalances between the parties.

\section{Conclusion}

It was noted above that the common law has objected to equity intervening to set aside contracts and gifts on the basis of equitable fraud. The objection is that parties should be held to agreements which they have voluntarily entered into. However, human behaviour is more

\footnotetext{
${ }^{111}$ McCulloch v Fern [2001] NSWSC 406, [61] (Palmer J)

${ }^{112}$ McCulloch v Fern [2001] NSWSC 406, [62] (Palmer J)

${ }^{113}$ Hartigan v International Society for Krishna Consciousness Inc [2002] NSWSC 810

${ }^{114}$ Hartigan v International Society for Krishna Consciousness Inc [2002] NSWSC 810, [94] (Bryson J)

${ }^{115}$ Hartigan v International Society for Krishna Consciousness Inc [2002] NSWSC 810, [94] (Bryson J)
} 
complicated than that. These cases show that equitable intervention is appropriate in certain circumstances, as religious devotion can easily be manipulated and exploited. This concern is no less today than it was either in the Middle Ages or in the $18^{\text {th }}$ and $19^{\text {th }}$ centuries.

The question remains as to when religious organisations can safely accept gifts without worrying about an undue influence claim being raised at a later time. There is no clear answer to this question other than that it is fact-dependent. There is nothing immediately wrong with a religious institution asking for a financial donation, nor by imposing mandatory tithes. Undue influence is not concerned with this daily occurrence of charitable donations and the law pragmatically recognises that such donations or tithes are required for the institution to operate. The concerns arise when there is some untoward spiritual pressure being placed on a person who, for whatever reason, is not in a position to make up their own mind. The psychological profiles from the cases considered are helpful in this respect, as they speak of the emotionally and spiritually vulnerable, aggravated by their being in a tight-knit community.

To protect themselves from potential undue influence claims, religious institutions should make clear that large gifts, including sizeable financial contributions, are not a religious imperative. Mandatory payments should be disclosed up front. Seeking to run a religion for profit (which would preclude the institution from having a charitable status) is of course not unconscionable in itself. In a free society anyone may seek to make a profit. However, an undue influence claim can afford protection to those who may have been tricked or pressured into joining a religious institution, or prevented from leaving by the application of pressure or threats. In each case, the courts will consider the size of the gift, the exact relationship between the donor and donee, and the circumstances in which the gift was granted. There is a difference between leaving pocket-change during collection at mass and deeding an entire farm. There is a difference between an occasional congregant granting a larger gift at a particular high holiday (such as Christmas within the Christian faith) and a gift given by someone residing within a closed community. Each of these situations of course still occurs in modern society; not exclusively within the Christian faith. These factual situations are all factors to take into account when the courts make a decision on undue influence. The benefit of the old cases, though firmly anchored in their particular societal context, is leading us to ask the right questions. 